\title{
De kracht van het begrijpen
}

Citation for published version (APA):

Rubio Gozalbo, E. (2019). De kracht van het begrijpen. Maastricht University. https://doi.org/10.26481/spe.20190111erg

Document status and date:

Published: 01/01/2019

DOI:

10.26481/spe.20190111erg

Document Version:

Publisher's PDF, also known as Version of record

\section{Please check the document version of this publication:}

- A submitted manuscript is the version of the article upon submission and before peer-review. There can be important differences between the submitted version and the official published version of record.

People interested in the research are advised to contact the author for the final version of the publication, or visit the DOI to the publisher's website.

- The final author version and the galley proof are versions of the publication after peer review.

- The final published version features the final layout of the paper including the volume, issue and page numbers.

Link to publication

\footnotetext{
General rights rights.

- You may freely distribute the URL identifying the publication in the public portal. please follow below link for the End User Agreement:

www.umlib.nl/taverne-license

Take down policy

If you believe that this document breaches copyright please contact us at:

repository@maastrichtuniversity.nl

providing details and we will investigate your claim.
}

Copyright and moral rights for the publications made accessible in the public portal are retained by the authors and/or other copyright owners and it is a condition of accessing publications that users recognise and abide by the legal requirements associated with these

- Users may download and print one copy of any publication from the public portal for the purpose of private study or research.

- You may not further distribute the material or use it for any profit-making activity or commercial gain

If the publication is distributed under the terms of Article $25 \mathrm{fa}$ of the Dutch Copyright Act, indicated by the "Taverne" license above, 


\title{
Maastricht University
}

Prof.Dr. M.E. Rubio Gozalbo

Faculty of Health, Medicine and Life Sciences

\section{De kracht van het begrijpen}

\author{
$\mu \varepsilon \tau \alpha b o \lambda l \sigma \mu o ́ s$
}




\section{De kracht van het begrijpen}

Inaugurele rede

Uitgesproken bij de aanvaarding

van de leerstoel Erfelijke metabole ziekten met focus op galactosemie (Inborn errors of metabolism with focus on galactosemia)

van de Universiteit Maastricht

op vrijdag 11 januari 2019

Prof. Dr. M.E. Rubio Gozalbo 


\section{Inhoudsopgave}

Mevrouw de Rector Magnificus

Erfelijke metabole ziekten in het algemeen en in het bijzonder galactosemie Het begrijpen van fouten in het erfelijk metabolisme

Het begrijpen van het belang van samenwerking

Het begrijpen dat reallocatie van middelen nodig is

Het begrijpen van de noodzaak van onderwijs

Vrouwen aan de top

Dankwoord 


\section{Mevrouw de Rector Magnificus, beste collega's en studenten, lieve vrienden en familie, zeer gewaardeerde toehoorders,}

Vandaag aanvaard ik de leerstoel Erfelijke metabole ziekten met focus op galactosemie.

Stel je voor dat je zojuist de ouder bent geworden van een mooi kind. Je droomt van een prachtige toekomst voor je baby, maar na een paar dagen wordt de baby ziek en wordt vervolgens steeds zieker. Dan ontvang je het nieuws dat je kind een erfelijke metabole ziekte (stofwisselingsziekte) heeft. Je hoop en dromen zijn verbrijzeld. Wat nu? Wat is metabolisme? Wat is deze ziekte? Wat kan eraan gedaan worden? Welke invloed heeft dit op het leven van mijn kind, en op onze familie?

\section{Erfelijke metabole ziekten in het algemeen en in het bijzonder galactosemie}

Laten we beginnen met het begrijpen van wat metabolisme is. Metabolisme of stofwisseling (uit het Grieks $\mu \varepsilon \tau \alpha B o \lambda ı \sigma \mu o ́ \varsigma$ "metabolismos") betekent verandering of omzetting. Het is het geheel van biochemische processen dat plaatsvindt in onze cellen waaruit verschillende chemische verbindingen ontstaan die we metabolieten noemen.

In de cel verlopen talrijke chemische processen allemaal op hetzelfde moment, dit is te vergelijken met een kleine, maar uiterst geavanceerde en efficiënte chemische fabriek. Dit vereist een strakke coördinatie en regulatie van al deze processen in de verschillende structuren in de cel waar deze processen in plaatsvinden. Het DNA speelt in deze coördinatie een cruciale rol, het codeert namelijk alle eiwitten die bij de chemische processen betrokken zijn en waar de celstructuren uit opgebouwd zijn. De belangrijkste processen die in de cel plaatsvinden zijn opbouw en verfijning, vervolgens transport, energie aanmaak en uiteindelijk ook weer de afbraak van de bouwstenen van de cel. In essentie zijn er vier typen bouwstenen waar alle levende organismen uit opgebouwd zijn: aminozuren (eiwitten), nucleotiden (DNA), koolhydraten en vetten (beiden energie).

Voor bijna elke chemische reactie in de cel is een enzym nodig om deze snel genoeg te laten plaatsvinden zodat we in leven kunnen blijven. De reeks stappen waarin een chemische stof met de hulp van enzymen wordt omgezet in andere chemische stoffen, noemen we een metabole route. Erfelijke metabole ziekten worden veroorzaakt door afwijkingen in deze metabole routes t.g.v. fouten in het DNA.

Er zijn heel veel metabole routes, allemaal met veel stappen. Je kunt je afvragen: waarom zo ingewikkeld? Veel stappen betekent veel tussenstoffen (metabolieten), die ook weer nodig zijn voor andere metabole routes. Veel stappen betekent ook dat de cel niet meer gebruikt dan nodig is, dat er geen verspilling ontstaat. In elke stap kan een fout ontstaan, daarom hebben we te maken met veel verschillende fouten die kunnen leiden tot velerlei erfelijke metabole ziekten, honderden, met sterk uiteenlopende uitingsvormen en ernst.

Elk jaar worden in Nederland 800 kinderen geboren met een van deze aandoeningen. Er zijn in Nederland veel gezinnen met kinderen met erfelijke metabole ziekten. Voor sommige ziektes is er nog geen behandeling en vele kinderen overlijden nog aan de gevolgen hiervan. 
Voor andere ziektes is er wel een behandeling, maar deze is niet in staat om de ziekteverschijnselen volledig te voorkomen waardoor patiënten, hun gezinnen en onze maatschappij met de vervelende gevolgen hiervan kampen. De zorg voor deze ziekten wordt in Universitaire Medische Centra (UMC) geconcentreerd omdat hiervoor bijzondere expertise, kennis en infrastructuur nodig is.

\section{Een metabole ziekte heeft grote impact!!}

\section{Het begrijpen van fouten in het erfelijk metabolisme}

Een voorbeeld van een metabole route is het galactose metabolisme. Galactose is een suiker aanwezig in vele voedingsstoffen, maar vooral in dierlijke melk in de vorm van lactose ofwel melksuiker. Eenmaal in de cel, wordt galactose in verschillende stappen omgezet in energie en in andere stoffen die nodig zijn voor complexe moleculen. Fouten in het DNA voor de verschillende stappen veroorzaken de groep van ziekten genaamd galactosemie. De meest voorkomende is klassieke galactosemie. Hierbij is er een fout in het stukje DNA dat het recept bevat voor het maken van het GALT-enzym. Maar, hoe is deze ziekte ontdekt?

De eerste beschrijving werd gedaan in 1908 (Von Reuss). Er werd een pasgeborene beschreven met het acute beeld van klassieke galactosemie: voedingsproblemen, slechte groei, braken, geelzucht, prikkelbaarheid, vergrote lever en staar onder andere. In het volgende decennium, werd de aanwezigheid van overtollige galactose in de urine van een eveneens getroffen baby gedocumenteerd (Göppert 1917). In 1935 werd het geval van een zuigeling met hoge galactose in bloed en urine (bloed: hypergalactosemie en urine: galactosurie) die goed reageerde op een dieet met lactosebeperking (geen borstvoeding/ dierlijke melk) beschreven (Mason en Turner 1935). Vele jaren later, in 1956 werd ontdekt dat galactose 1-fosfaat verhoogd was in rode bloedcellen van deze patiënten (Schwarz et al.) en werd GALT geïdentificeerd als het enzym dat niet goed werkte. (Isselbacher et al. 1956). Pas in 1988, werd het GALT-gen geïdentificeerd (Reichardt and Berg 1988).

Maar wat gebeurt er precies met galactose in onze cellen? Voor het begrijpen van het metabolisme moeten we altijd terug naar de biochemie. Het was Federico Leloir die de stappen in deze route heeft opgehelderd. Hij was een geneeskunde student die fysiologie beter wilde begrijpen en daardoor biochemie is gaan studeren. Zijn werk heeft ons geleerd dat de suiker galactose eerst wordt omgezet in galactose-1-fosfaat om vervolgens in een pingpong reactie m.b.v. UDP-glucose omgezet te worden tot glucose-1-fosfaat en UDPgalactose. Terwijl glucose-1-fosfaat als energiebron gebruikt wordt, zijn UDP-galactose en UDP-glucose suiker donoren voor andere reacties. 


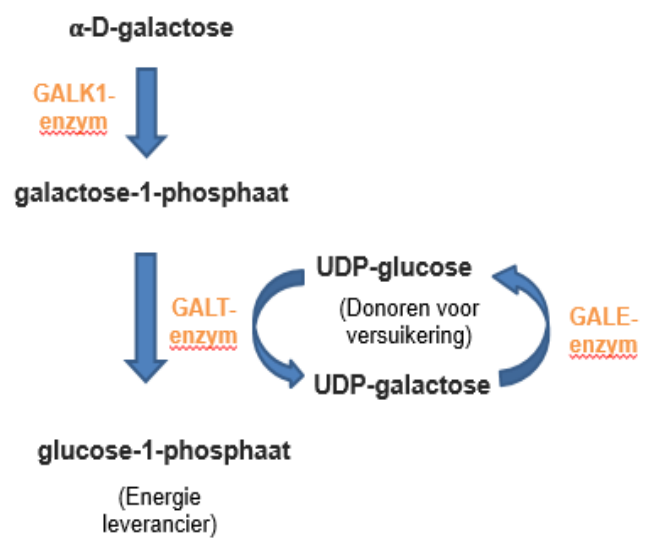

Figuur 1: Galactose metabole route: GALK1-, GALT-en GALE-enzym weergave.

GALK1: galactokinase, GALT: galactose 1-phosphaat uridylyltransferase, GALE: UDPgalactose 4-epimerase.

We kunnen met deze kennis begrijpen waarom pasgeborenen met fouten in deze metabole route hoge galactose in bloed en urine ontwikkelen. De enorme hoeveelheid aan galactose aanwezig in moedermelk of flesvoeding kan niet verwerkt worden en is in verhoogde mate in lichaamsvloeistoffen aanwezig. Er is een te veel aan bepaalde stoffen en een tekort aan andere wat tot ziekteverschijnselen leidt. Met het instellen van het dieet klaart het ziektebeeld op en de kinderen doen het goed totdat zij iets ouder zijn. Tussen 1970 en 1990 werd steeds duidelijker dat dieet het ernstige klinische beeld van de pasgeborene oplost maar het ontstaan van complicaties niet voorkomt. Helaas ontwikkelen de meeste patiënten, ondanks hun dieet, complicaties die vooral de hersenen en eierstokken treffen, resulterend in cognitieve, gedrags- en neurologische complicaties in zowel vrouwen als mannen (85\%) en subfertiliteit bij vrouwen (80\%). Bovendien lopen patiënten het risico op een verminderde botdichtheid (26\%) (Bron: internationale galactosemie patiënten data register).

Dit betekent dat er nieuwe, betere behandelingen nodig zijn. Hiervoor is meer begrip nodig

We kunnen patiënten beter gaan behandelen, we kunnen onbehandelbaar, behandelbaar maken

over het beloop van de ziekte en de ziektemechanismen. Naarmate ons begrip van deze ziekten toeneemt kunnen we betere diagnostische hulpmiddelen ontwikkelen en nieuwe therapieën onderzoeken gericht op betere toekomst voor de patiënten en hun families. We kunnen patiënten beter gaan behandelen, we kunnen onbehandelbaar, behandelbaar maken. Echter, dit is een proces dat sterk afhangt van samenwerkingsverbanden, open wetenschap en beschikbare middelen.

\section{Het begrijpen van het belang van samenwerking}

In het verleden werkten clinici en onderzoekers vooral vanuit hun eigen perspectief. Maar nu verdwijnen de grenzen tussen de verschillende disciplines. Geïntegreerde theorieën over hoe processen op verschillende niveaus met elkaar in verband staan en elkaar beïnvloeden, 
kan alleen door het bundelen van krachten en multi- en interdisciplinaire benaderingen. Begrip hiervoor is een vereiste voor vooruitgang. Samenwerken vraagt om een open houding, om vertrouwen, om transparantie, om elkaar dingen gunnen, om de ego's te parkeren ergens waar zij samenwerking niet in de weg staan, om het gezamenlijke doel niet uit het oog te verliezen. Dit is wat we ons moeten blijven realiseren en aan de nieuwe generaties moeten overbrengen. Het bundelen van krachten is geen keus, het is een voorwaarde.

Vanuit de overtuiging van het belang van samenwerken, ben ik in 2009 de mogelijkheden van het oprichten van een internationaal Galactosemie netwerk gaan exploreren. In 2009 en 2011 heb ik de eerste en tweede internationale galactosemie workshop georganiseerd in het MUMC+ met NWO-subsidies, en in 2012 is het galactosemie netwerk (GalNet) opgericht.

Inmiddels nemen professionals uit 20 verschillende landen hieraan deel. Het GalNet is opgericht met onder andere steun van de Nederlandse en Europese Galactosemie Patiënten Verenigingen. Netwerken van professionals zijn cruciaal, maar kunnen niet zonder netwerken van patiënten. Heel belangrijk voor galactosemie behandeling, begeleiding en onderzoek in Nederland en in Europa, is het bestaan van de Nederlandse Galactosemie Vereniging onder de leiding van Jeroen van Bruggen en Karen 't Hoofd en de Europese Galactosemie Vereniging met Jeroen en Maaike van Kempen als voorzitter en vicevoorzitter.

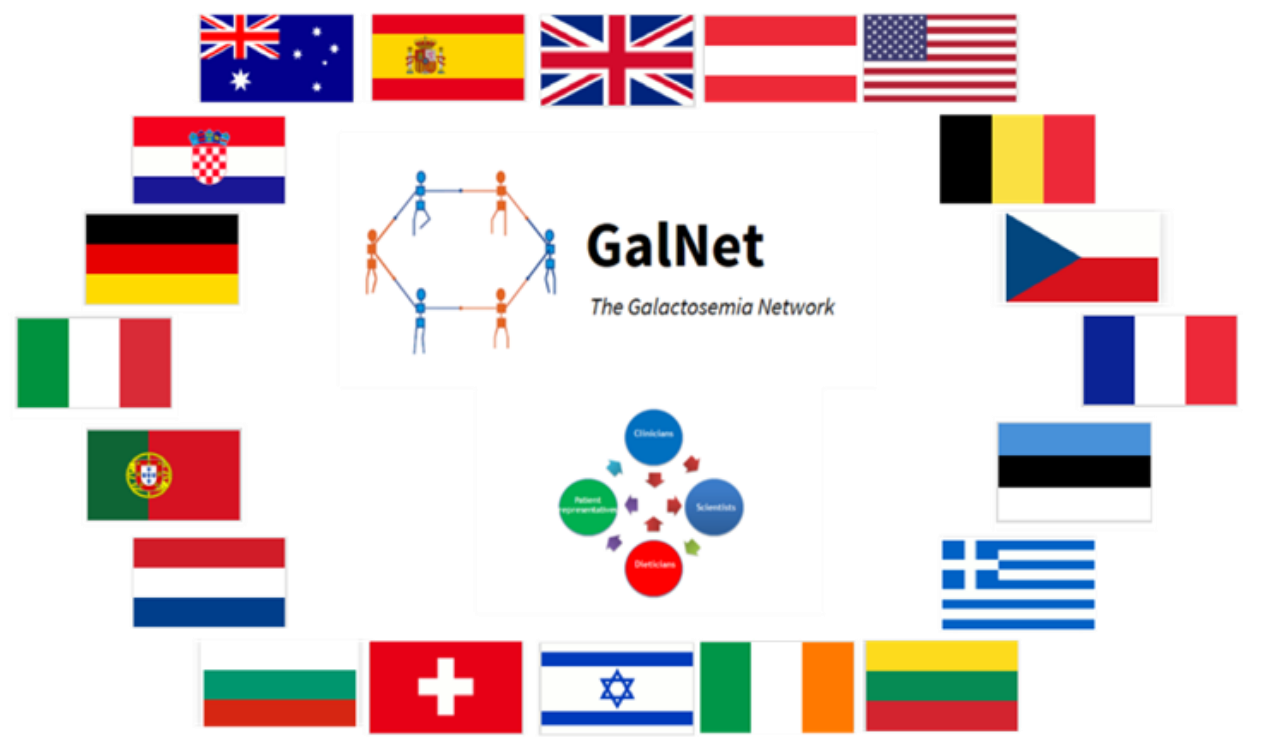

Figuur 2: Galactosemia Network (GalNet).

Het GalNet richt zich op de bevordering van onderwijs, onderzoek, diagnose, behandeling en nazorg van galactosemiepatiënten door hechte samenwerking tussen clinici, onderzoekers en voedingsdeskundigen en patiënt organisaties. Sinds de oprichting hebben we samen een aantal belangrijke doelen bereikt en zijn we volop bezig om de weg naar een optimale zorg 
en behandeling te bewandelen. Wat is de kracht van zo een netwerk? Wat kunnen we samen doen? Laat ik een paar voorbeelden noemen.

In 2017 zijn richtlijnen voor diagnostiek, behandeling en vervolg van patiënten met de meest voorkomende vorm van galactosemie gepubliceerd onder de bezielende leiding van mijn collega Dr. Annet Bosch van het UMC Amsterdam. De volgende stap is dat deze richtlijnen bekend zijn en gehanteerd worden onder betrokken professionals en patiënten. Alleen publiceren is niet voldoende. Er wordt nu gewerkt aan een strategie voor disseminatie en implementatie geleid door een collega uit Denver en de vicevoorzitter van de Europese Galactosemie Vereniging Maaike van Kempen.

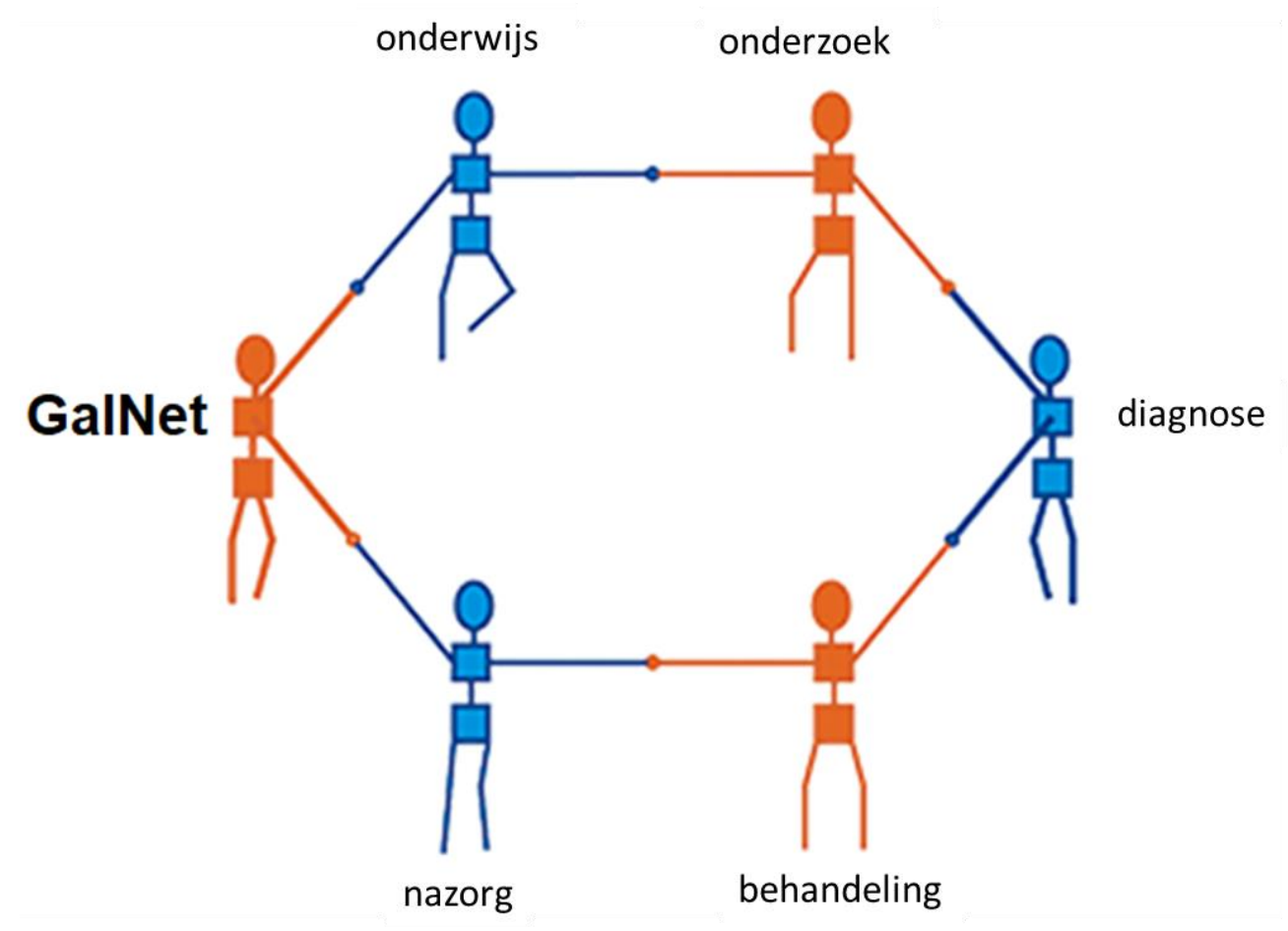

Figuur 3: GalNet richt zich op onderwijs, onderzoek, diagnose, behandeling én nazorg.

In 2019 wordt het natuurlijk beloop van klassieke galactosemie gepubliceerd gebaseerd op data van 509 patiënten uit 32 centra in 15 verschillende landen uit het internationale patiënten register dat ik coördineer. Voor een zeldzame ziekte, zijn dit grote getallen. Voor het ontwikkelen van nieuwe behandelingen, is het conditio sine qua non dat het natuurlijk beloop van een ziekte gebaseerd op een groot aantal data, bekend is.

Daarnaast zijn we volop bezig met het ontwikkelen van nieuwe therapieën voor galactosemie gebruik makend van de meest nieuwe inzichten en technologieën in ons veld. Met deze kennis en middelen kunnen we samen met andere toonaangevende metabole centra de weg naar betere behandelingen inslaan. Belangrijke recente bijdragen van onze MUMC+ galactosemie onderzoeksteam zijn geweest 1- het ontwikkelen van een zebravis dierenmodel voor deze ziekte en 2 - het identificeren van de neuronale netwerken die verband houden met de cognitieve problemen van deze patiënten. 
Hoe zou een nieuwe behandeling eruit kunnen zien? Laat ik een aantal voorbeelden noemen van veelbelovende aanpakken waarmee we nu bezig zijn. De eerste is correctie van de DNA fout gebruik makend van mRNA therapie. Dit is een vorm van gen therapie, waarbij i.p.v. het fout direct te repareren, aan de cel het goede recept voor de aanmaak van het specifieke enzym wordt aangeboden. mRNA, of messenger RNA, is RNA dat nucleotide voor nucleotide overgeschreven is van een gen. Aan de hand van de nucleotidenvolgorde in dat mRNA, wordt vervolgens een eiwit samengesteld uit aminozuren. Een fout in het GALT gen betekent dat de mRNA een afwijkend nucleotidenvolgorde bevat wat resulteert in een GALT-enzym met een verkeerde aminozuur samenstelling en daardoor niet goed werkzaam. Door het juiste mRNA toe te dienen, overbruggen we het defect. De tweede is verbetering van de stabiliteit en de werkzaamheid van het GALT-enzym door kleine farmacologische moleculen toe te voegen. Door fouten in het GALT gen wordt een enzym gemaakt die veel minder stabiel is, kleine farmacologische moleculen kunnen hierbij behulpzaam zijn. Voor beide strategieën zal het effect hiervan in ons zebravis model essentiële informatie leveren. Het bestaan van de GalNet en patiënten register samen met de Europese patiëntenvereniging vormen een geweldig platform om de preklinische resultaten later te vertalen naar de klinische fase.

Een andere veelbelovende aanpak is niet invasieve hersenstimulatie (NIBS) waarbij via elektrodes wisselstroom in bepaalde frequenties toegediend wordt aan aangetaste neuronale netwerken om deze te moduleren met een gunstig effect. Dit laatste is het resultaat van een prachtige samenwerking met Prof. dr. Bernadette Jansma en dr. Teresa Schuhmann van het Maastricht Brain Imaging Center (M-Bic).

Hiermee zijn we volgens de MUMC+ innovatiecirkel nieuwe kennis aan het opdoen en in de praktijk aan het brengen, scheppen we er waarde mee en bevorderen we de gezondheid van patiënten met erfelijke metabole ziektes.

Alle bovenstaande was niet mogelijk geweest zonder de krachten te bundelen. Deze samenwerkingsverbanden zijn niet altijd makkelijk, blijft mensen werk, intermenselijke relaties en uiteenlopende belangen kunnen in de weg staan. Het medicijn hiervoor is het gezamenlijke doel voor ogen houden en hopen dat iedereen het medicijn consequent inneemt.

Als metabool centrum zien we een heel breed spectrum aan metabole ziekten. Voor deze hele groep is er meer heugelijk nieuws. Recentelijk is United for Metabolic Diseases (UMD) opgericht, een geweldig initiatief van onze collega's van het Amsterdam UMC (dr. Clara van Karnebeek en Prof. dr. Hans Waterham). Dit is een uniek samenwerkingsverband tussen artsen en onderzoekers van zes verschillende UMCs, waaronder het MUMC+, en patiëntenvereniging "Vereniging voor kinderen en volwassenen met stofwisselingsziekten" om diagnostiek en behandeling te versnellen en te verbeteren. Financiering is mogelijk door Stichting Metakids en de VriendenLoterij. Deze initiatief wordt ondersteund door de Number 5 Foundation, opgericht door prinses Laurentien en haar man, om innovatieve maatschappelijke projecten een podium te bieden om gedeelde ambities te realiseren. 
Afgelopen jaar is nog een belangrijke samenwerkingsverband tot stand gekomen voor ons ziekenhuis, De Academische Alliantie tussen het MUMC+ en het Radboudumc. De afdelingen klinische genetica met daarin laboratorium metabole ziekten en de metabole collega's van het transmurale metabole laboratorium Nijmegen werken intensief samen om voor de diagnostiek een virtueel centrum te creëren. Hiermee wordt een aanzienlijke verbetering van efficiëntie en gebruik van dure infrastructuur gerealiseerd. Voor het klinische deel, kindergeneeskunde metabole ziekten, zijn we bezig om onze samenwerking te intensiveren. Voor onderzoek zijn we begonnen met het benutten van onze gedeelde belangstelling voor nucleotide suikers en werken met Prof. Dr. Dirk Lebefer aan het ophelderen van hoe afwijkingen hieraan gerelateerd zijn aan ziekteverschijnselen.

Laat ik $\mathrm{u}$ ook een voorbeeld geven van hoe we werken in de kliniek. Een jongen wordt opgenomen met klachten nadat hij flink gesport heeft. Hij heeft cola-kleurig urine en enorme pijn in zijn spieren. Deze klachten passen bij spierafbraak. Omdat hierbij de nier bedreigd is, worden de nodige maatregelen om de dreigende nier schade te voorkomen en parallel hieraan wordt een diagnostische work-up ingezet waarin een erfelijke metabole ziekte wordt overwogen. Deze presentatie kennen we onder andere bij defecten in de verbranding van lange keten vetzuren. Dit zijn de vetten aanwezig in onze voeding die we verbranden om energie vrij te maken. Er worden een aantal diagnostische testen gedraaid en we kunnen aan de uitslag afleiden dat er inderdaad een specifiek defect is in de afbraak van lange keten vetzuren. We kunnen deze diagnostiek op metaboliet niveau snel doen, in een aantal uren. Bevestiging op enzymatisch en genetisch niveau duurt langer, maar is voor de acute situatie niet nodig. Deze uitslag betekent dat naast bescherming van de nier, genoeg energie in de vorm van suiker via een infuus gegeven moet worden om het ziekteproces halt toe te roepen. Deze diagnose geeft duidelijkheid en opent de deuren naar een adequate behandeling. Dat dit proces soepel verloopt veronderstelt de juiste kennis van alle deelnemers aan dit proces, noodzakelijke infrastructuur (denk bv aan de metabole laboratorium), excellente communicatie tussen allen deelnemers aan het proces, inclusief patiënt en familie, alsmede een feilloze logistiek.

\section{Het begrijpen dat reallocatie van middelen nodig is}

De grote diversiteit, complexiteit en zeldzaamheid van erfelijke metabole ziekten vraagt om meer gerichte aandacht en financiële ondersteuning van de kostbare infrastructuur en wetenschappelijk onderzoek. Dit is nodig om in de komende jaren de toekomstperspectieven voor patiënten en hun families te verbeteren. In ons centrum is het aantal clinici betrokken bij erfelijke metabole ziekten erg gering. Het aantal gediagnosticeerde patiënten met deze ziektes neemt toe, het aantal patiënten die de ziekte overleeft en chronisch patiënt wordt neemt eveneens toe. Daarnaast, is er, door de uitbreiding van de neonatale screening in 2007 met een aantal metabole ziekten, een gestage toename van het aantal gediagnostiseerde patiënten. De aankomende extra uitbreiding zal dit alleen versterken. Dit is een enorm spanningsveld. Waarom zou er zoveel geld uitgegeven worden om patiënten te vinden met neonatale screening en wordt zo weinig geïnvesteerd in de lange termijn zorg van deze mensen? Door de neonatale screening en beter wordende behandeling komen we steeds weer voor nieuwe vragen te staan. We zullen met de nieuwe samenwerkingsverbanden onze kwetsbaarheid verminderen. Echter, om deze 
samenwerkingsverbanden te bestendigen, is het ook nodig om de bestaande middelen zodanig te verdelen dat we ook patiënten met deze groep ziekten optimaal kunnen behandelen.

Patiënten met zeldzame erfelijke metabole ziektes hebben hetzelfde recht op optimale zorg als patiënten met meer voorkomende ziekten. Vele van de grote vooruitgangen die geboekt zijn in de geneeskunde zijn terug te voeren op het begrijpen van het erfelijke metabolisme.

Tegenwoordig wordt societal impact als een van de indicatoren voor het financieren van onderzoek gebruikt. Dit maakt het voor veel voorkomende ziektes relatief makkelijk om de competitie te winnen in ons socio-economisch gedreven model. Maar als we terug gaan naar het begin van mijn verhaal, en $u$ bent de ouder van de baby met een erfelijke metabole ziekte, wilt $u$ ook dat de behandeling optimaal is. Het is voor $u$ niet relevant dat het zeldzaam is, maar dat het uw kind is met recht op optimale zorg.

De ziekten individueel zijn zeldzaam maar als groep veel voorkomend. De laatste jaren staan deze ziekten gelukkig vaker op nationale en internationale agenda's maar er is nog veel meer te bereiken. Veel van de principes die uitgezocht en toegepast worden in mijn veld, zijn zeer relevant voor meer voorkomende ziektebeelden.

\section{Het begrijpen van de noodzaak van onderwijs}

Als $u$ de ouder bent van de zieke baby waarmee ik mijn rede begonnen ben, verwacht $u$ dat de arts de ziekteverschijnselen erkent als mogelijk passend bij een erfelijke metabole ziekte en dat prompt de juiste maatregelen genomen worden. Dit veronderstelt echter dat de arts idealiter al in het medisch curriculum tijdens de studie geneeskunde in aanraking is gekomen met deze groep ziekten. Dat is helaas nog niet altijd zo, deze ziekten zijn erg onbekend en vaak wordt er niet of te laat aan gedacht. Hier ligt voor universiteiten als verantwoordelijke voor de medisch curricula de taak om meer aandacht te besteden aan biochemie en erfelijke metabole ziekten. Kennis nemen van het belang hiervan is essentieel voor deze groep van ziektebeelden die onvoldoende bekend zijn en daardoor, onvoldoende erkend worden. Velen van ons werkzaam als universitair docent moeten de verantwoordelijkheid nemen om aandacht te vragen en met voorstellen te komen om dit onderwijs te implementeren. In het curriculum geneeskunde van de Universiteit Maastricht is een optioneel blok voor studenten in het $2^{\mathrm{e}}$ jaar over erfelijke metabole ziekten opgenomen, een mooi begin.

Niet alleen is het van belang de nieuwe generatie medici de kennis over erfelijke metabole ziekten mee te geven, minstens even belangrijk is het om vooral het herkennen van deze groep van ziekten te vergroten bij ervaren artsen, van huisarts tot academisch medisch specialist.

\section{Vrouwen aan de top}

Ik wil een moment stil staan als vrouwelijke hoogleraar bij het thema vrouwen aan de top. Enkele jaren geleden heb ik een traject gevolgd voor vrouwelijk talent in het MUMC+. Het is 
belangrijk dat organisaties dit soort initiatieven ondersteunen. Vrouwelijk talent is er, niet altijd goed zichtbaar, maar wel vindbaar. Ik probeer als arts, onderzoeker, docent en nu als hoogleraar een rol model te zijn voor vele vrouwelijke talentvolle bedreven collega's, PhD's en studenten. Ik heb in het MUMC+ en UM veel vrouwen die een rolmodel voor mij zijn, en die me geïnspireerd hebben en blijven inspireren in mijn carrière. Verspilling is zonde, dus laten we streven om geen vrouwelijk talent te verspillen, daar zullen we allen profijt van ondervinden. Willen we dit bereiken, zullen ook de vrouwen zelf hun manier van denken moeten veranderen.

\section{Dankwoord}

Ik ben het College van Bestuur zeer erkentelijk voor het vertrouwen in mijn persoon met het instellen van deze leerstoel. Het veld van erfelijke metabole ziekten maakt grote vorderingen, er worden meer patiënten gediagnosticeerd, er komen meer behandelingen beschikbaar, meer patiënten overleven en worden volwassen. $\mathrm{Er}$ is een toenemend maatschappelijk bewustwording op de verschillende niveaus dat deze patiënten dezelfde zorgstandaards verdienen als patiënten met meer algemene aandoeningen. De voorgestelde activiteiten met betrekking tot deze leerstoel zijn gericht op de bijdrage aan deze doelstelling voor het MUMC+.

Ik voel me enorm bevoorrecht dat ik dit werk, mijn passie, kan uitoefenen en hiermee kan bijdragen aan dit proces maar vooral dat ik omringd ben door fantastische collega's, vrienden, familie en mijn grote steunpilaar, mijn gezin.

Ik wil in het bijzonder de vakgroep voorzitter van kindergeneeskunde Prof. Dr. Luc Zimmermann hartelijk bedanken. Ook veel dank aan de vakgroep voorzitter van de Klinische genetica, Prof. Dr. Han Brunner en de directeur van onderzoeksinstituut GROW Prof. Dr. Manon van Engeland.

Heel veel dank ook aan mijn dierbare collega's van de kindergeneeskunde en de klinische genetica. Er waait een enorme frisse wind op beide afdelingen, we zijn zeer goed bezig en het is een voorrecht om hier onderdeel van te zijn.

Prof. Dr. Connie Stumpel wil ik ook hartelijk bedanken voor het regelmatige brainstormen vol wijze raad. Ook dank aan Prof. dr. Jan Smeitink van het Radboudumc, waar ik ben opgeleid in de metabole ziekten en gepromoveerd onder zijn bezielende leiding.

Er zijn veel nationale en internationale collega's die me heel dierbaar zijn, een aantal zijn hier vandaag aanwezig. Heel veel dank dat jullie er zijn, het maakt deze dag nog bijzonderder. Twee wil ik persoonlijk bedanken vanwege onze bijzondere vriendschap. Dr. Stephanie Grunewald, uit Great Ormond Street Hospital in Londen, and Prof. dr. Gerard Berry uit Boston Children's Hospital, Harvard Medical School.

Marike Groenendijk wil ik ook bedanken. Zij is voorzitter van Stofwisselkracht, een stichting dat fondsen werft voor stofwisselingsziekten, waarmee heel veel onderzoek in Nederland de laatste jaren is gefinancierd. 
Daarnaast wil ik de leden van ons metabole team persoonlijk bedanken, dr. Jorgen Bierau, dr. Daphna Habets, dr. Irene Keularts, dr. Laura Steinbusch, Liesbeth van de Ploeg en dr. Martijn Brouwers. Jullie zijn geweldig, en het is enorm plezierig om met jullie de metabole uitdagingen aan te gaan. Ook dr. Joost Nicolai, een onmisbare kracht om zeer uitdagende neurometabole puzzels op te lossen, wil ik persoonlijk bedanken.

Zeer bijzonder voor mij zijn de kernleden van mijn onderzoeksteam: dr. Ana Coelho, al jaren mijn rechterhand, dr. Jo Vanoevelen, onze zebravis deskundige, onze huidige ijverige en talentvolle PhD's Minela Haskovic en Britt Derks en weer dr. Jorgen Bierau, we doen zowel kliniek als onderzoek samen, en dat is erg leuk. We hebben heel intensief en hard gewerkt maar de resultaten mogen er zijn. We zitten in een achtbaan van nieuwe ontwikkelingen, mogelijkheden, en uitdagingen die hele spannende tijden beloven. Vele van jullie zijn niet alleen collega's maar ook hele goede vrienden.

Ook heel veel dank aan Dyonne Schols, onze uitstekende secretaresse en altijd het zonnetje in huis. Jij bent in een woord geweldig!

En dan, mijn dierbare familie, mijn lieve ouders zijn er niet meer, maar zij zouden enorm trots zijn. Het was voor hun een schok dat ik als jong meisje naar Nederland vertrok omdat ik een bijzondere Amsterdamse jongen had leren kennen. Zij hebben me twee eigenschappen bijgebracht, bescheidenheid en hard werken.

Mijn lieve zus, Xelo, hier aanwezig, mil gracias. Mijn Nederlandse familie, ik had het niet beter kunnen treffen. In het bijzonder mama, wil ik bedanken. Van jou heb ik geleerd om altijd de positieve kant te zien.

Als laatste, mijn kinderen, Robert en Arthur, de vriendin van Robert, Amber en mijn lieve echtgenoot, Henk. Robert en Arthur, jullie zijn twee geweldige jongens. Jullie brengen enorm veel geluk in mijn leven en ik ben zeer trots om jullie mama te zijn. Amber, jij bent een bijzonder fijne meid en ik ben erg blij met jou komst in ons gezin. Henk, mijn rots, de bijzondere Amsterdamse jongen voor wie ik naar Nederland verhuisde. Jij bent van iedereen het meest trots op mij, dankjewel.

“Ik heb gezegd." Prof. dr. M. Estela Rubio Gozalbo 